Çukurova Üniversitesi Mühendislik Mimarlık Fakültesi Dergisi, 29(2), 79-93 ss., Aralık 2014

Çukurova University Journal of the Faculty of Engineering and Architecture, 29(2), pp.79-93, December 2014

\title{
PVC ve PET Atıkların Seçimli Flotasyonu Bölüm 1: Plastikler; Çevresel Etkileri; Geri Dönüşümü
}

\author{
Mert KILIÇ ${ }^{1}$, A. Ekrem YÜCE ${ }^{* 2}$ \\ ${ }^{I}$ Troia Madencilik Ltd. Şti. Hurmaköy, No:14 Çan/Çanakkale \\ ${ }^{2}$ İTÜ Maden Fakültesi, Cevher Hazırlama Mühendisliği Bölümü, İstanbul
}

Özet

Geliş tarihi: 18.10.2014 Kabul tarihi: 3.12.2014

Plastiklerin doğada uzun süre kalarak çevre kirliliğindeki ciddi tehlikelerden biri olması ve dünya plastik tüketiminin giderek artması, bu maddelerin geri dönüşümünü gündeme getirmiştir. Geri kazanımı üzerinde durulan en önemli iki plastik türü Polietilen Teraftalat (PET) ve Polivinil Klorür (PVC)'dür. PVC'lerde bulunan katkı maddelerinin çevreye zehirli gazlar ve hidroklorik asit karıştırma riskinden dolayı, bu zararları önlemek adına PET ve diğer plastiklerden ayrılması için çalışmalar yapılmaktadır. Plastiklerin yoğunlukları birbirine yakın olduğundan dolayı, gravite yöntemleri ile ayrılması söz konusu değildir, fakat yüzey özelliklerinden yararlanılarak PET ve PVC'den biri hidrofilik yapılıp bastırılırken diğerinin yüzdürülerek köpükle alınması mümkündür. Doğal hidrofobik olan plastiklerden hidrofilik olması istenen plastiğin yüzeyi değiştirilmesi gerekir ve bu sebeple plastikleştirici reaktifler kullanılır. İki bölümden oluşan bildirinin birinci bölümünde plastikler, çevresel etkileri ve geri dönüşüm prosesleri hakkında genel bilgiler verilmiştir.

Anahtar Kelimeler: Plastik atık, Geri kazanım, PET, PVC, Kolon flotasyonu

\section{Selective Flotation of PVC and PET Wastes Part 1: Plastics, Environmental Effects, Recycling}

\begin{abstract}
Recycling of plastic wastes became an important issue because of the negative effects of these materials. PVC causes harmful gases and hydrochloric acids in the environment, so PVC should be separated from PET and other plastics. There is no such gravity difference between plastics, so they couldn't be separated by gravity methods. Flotation method has applicability and low costs for seperating PET and PVC wastes, so it is the most preferred method, but the surface characteristics of PET and PVC must be changed. Because, all plastics are naturally hydrophobic. So that, they can only be separated while one of these plastics is hydrophilic. Hydrophilic material is depressed and the other one floats. Plasticizer reagents are used to change the plastics' surface character and make them hydrophilic. In this first part of paper having two parts, general properties of plastics, environmental effects and recycling methods are summarized.
\end{abstract}

Key Words: Plastic waste, Recycling, PET, PVC, Column flotation

Yazışmaların yapılacağı yazar: Mert KILIÇ, Troia Madencilik Ltd. Şti. Hurmaköy No:14 Çan/Çanakkale.mertkilic95@hotmail.com 


\section{GIiRiş}

Plastikler, petrol ve doğal gaz gibi doğal kaynaklardan elde edilen hidrokarbonların kullanımı ile üretilmektedir. Bir başka deyişle, monomerlerin kimyasal bağlarındaki değişiklik ile polimerlere dönüşmesi sonucunda plastikler elde edilmektedir. Plastikler, termoplastikler ve termosetler olmak üzere iki temel tiptedir. Plastiklerin özelliklerini, polimer molekülün yapısı ve büyüklüğü belirler. Termoplastikler, 1sıtılınca yumuşarlar ve soğutulduklarında tekrar sertleşirler. Termosetler ise bir defa kalıplandıktan sonra asla yumuşamazlar. Plastikler toz, granül, kepek ve çözelti şeklinde olabilmektedir. Katı maddelerin 1sı ve basınç ile muamele edilmesi sonucunda günlük hayatımızda yakından tanıdığımız birçok ürün üretilmektedir [1].

Katı atıklardan plastiklerin geri kazanılması günümüz çevre konularının en aktif olanlarından birisidir. Bu çalışmaların kapsamında özellikle şişe uygulamaları nedeniyle PVC'nin giderek önem kazanan ayrı bir yeri bulunmaktadır. Katı atıklar içerisinde yer alan plastiklerin diğer bir bölümünü oluşturan film halindeki plastik atıklarda da ayırma işlemi söz konusudur. Bunun için, iri parçalar halinde kesilen atıklar önce titreşimli banttan sonra bir mıknatıstan geçirilmekte; daha sonra çöktürme tankına gönderilmektedir. Böylece, kirleticilerden temizlendikten sonra malzeme ayrım işlemine geçilmektedir. Bunun için de genellikle flotasyon ve hidrosiklon yöntemleri kullanılmaktadır. Elde edilen ürünler kurutulduktan sonra peletlenerek pazarlanmaktadir [2].

Günlük hayatta kulanılan plastik şişelerin en yaygın görülen çeşitleri Polietilen Teraftalat (PET) ve Polivinil Klorür (PVC)'dür. Geri kazanılan PET'in içerisindeki PVC'nin varlığı, PVC'nin bozulması esnasında mikro moleküller sayesinde gelişen hidroklorik asidin zincir bölünmesi nedeniyle çok tehlikelidir. PVC'nin ortama saldığ bu hidroklorik asidin çevreye olan zararları yüksektir [3,4].

İki bölümden oluşan bildirinin bu bölümünde; plastikler, genel özellikleri, çevresel etkileri ve geridönüşüm yöntemleri verilmekte olup, bildirinin ikinci bölümünde ise; PVC ve PET atıklarının kolon fotasyonu ile seçimli olarak ayrılmasında, laboratuvar ve pilot ölçekli deneylerde flotasyon parametreleri incelenerek, koşulların optimizasyonuna ilişkin sonuçlar tartışılacaktır.

\section{PLASTÍKLER}

Plastikler, yüksek molekül ağırlıklı organik moleküllerden ya da polimerlerden oluşmaktadır. Organik moleküller ve polimerler, birbirine kimyasal olarak bağlı birimlerin yinelenmesiyle ortaya çıkan zincir yapılardır. Plastik, istenilen biçimi alabilen anlamına gelen yunanca "plastikos" sözcüğünden gelir.

Ticari olarak yapılan ilk plastikler yarı sentetiktir. Bunlar, genellikle pamuk artıklarından elde edilen ve insanların sindiremediği bir karbonhidrat olan selülozdan türetilmiştir. 1868 y1lında İngiliz Kimyacı Alexander Parkes, kolayca kalıplanabilen ve biçimlendirilebilen, "Parkenise" adlı bir plastik hazırlamış ancak endüstri ölçeğinde üretimi başarısızlıkla sonuçlanmıştır. 1870 yılında ABD'de matbaaci John Wesley Hyatt, ticari bakımdan ilk başarılı plastik olan selüloidi Parkensin'e benzer biçimde, ama hintyağı yerine kafurun kullanarak hazırlamıştır. Hyatt'in buluşu kafurunun plastikleştirici etkisidir. Bu yeni madde, gözlük çerçeveleri, taraklar, bilardo topları, bıçak ve fotoğraf filmi gibi çok çeşitli ürünlerin yapımında kullanılmıştır. Selüloz nitrat ve türevlerinin yanıcı özelliğe sahip olması nedeniyle 1900'lerin başında yerini selüloz asetata bırakmıştır. 1907 yılında Belçikalı kimyager Leo Baekland çok sert ve koyu renkli bir plastik olan bakaliti üretmiştir. $\mathrm{Bu}$ madde tümüyle sentetik olan ilk plastiktir. Baekland, kendi tasarladığ 1 ve adına "bakalizer" dediği bir düzenekle sıcaklığ basıncı değiştirerek uçucu kimyasalların tepkimelerini kontrol etmiştir. $\mathrm{Bu}$ malzeme yanmayan, erimeyen ve bilinen çözücülerle çözünmeyen, sertleştikten sonra değişmeyen bir malzemedir. Böylece ilk termoset plastik üretilmiş olmaktadır. Fenol formaldehit reçinesi olan bakalit telefon ahizeleri gibi plastik ürünlerin yapımında kullanılmıştır $[5,6]$. 
Herman Staudinger, 1922 yılında yaptı̆̆ 1 bir çalışmada, plastiklerin küçük moleküllerin birleştirilmesiyle oluşan dev moleküller ya da polimerler olduğunu göstermiştir. Staudinger, yaptığ1 büyük çapta incelemelerin sonucunda, plastiklerin zincir şeklinde makromoleküllerden oluştuğunu ve bu moleküllerin birbiriyle kovalent bağlanan küçük ünitelerden meydana geldiğini göstermiştir. Benzer moleküllerin polimer zincirleri oluşturacak biçimde bağlanması anlamına gelen polimerizasyon işlemi ile polimer sanayi hızla gelişmiş ve 1927 'de Selüloz Asetat ve Polivinil Klorür, 1928'de Polimetilmetakrilat, 1929'da üre-formaldehit reçineleri elde edilmiştir. Bunlar1 daha sonra 1932'de Polietilen, 1934'te naylon, Poliakrilonitril, Stiren-akrilonitril ve Polivinil Asetat, 1937'de Poliüretan, 1939'da teflon ticareti adiyla tanınan Poli (tetrafloroetilen), 1941'de Polietilen Tereftalat ve orlon ticari adiyla tanınan Poliakrilonitril fiber takip etmiştir. İkinci Dünya Savaşı plastik endüstrisinin gelişiminde en önemli etkenlerden birisi olmuştur. Polivinil Klorür'ün önemi bu yıllarda ortaya çıkmış ve özellikle müzik sektöründe çok ilgi görmüştür. 1950'lerde ise müzik plakları üretiminde Polivinil Klorür'ün kullanılması, PVC tüketiminin önünü açmıştır. Otomotiv sektöründe plastik kullanımı ise 1950'lerde başlamıştır [5,6].

Bütün plastikler polimerizasyon ürünüdür. Plastik yapımının ön işlemi bunların monomerlere çevrilmesidir. Etilen gazı en yaygın olarak kullanılan monomerlerden birisidir. Sicaklık, basınç ve birçok kimyasalın etkisiyle plastik üretiminin ikinci evresi başlamaktadır. Buna, "polimerizasyon" denmektedir. Monomerler, zincir oluşturacak biçimde birbirine bağlanmakta ve rezinleri oluşturmaktadır. Etilen Polietilen'e, Propilen Polipropilen'e, Stiren Polistiren'e dönüşmektedir. Böylece, polimer veya plastikler meydana gelmektedir [5].

\subsection{Plastik Türleri}

Plastikler, 1sitıldığında erimeyen plastikler (termoset) ve isıltıldığında eriyebilen plastikler (termoplastik) olmak üzere iki gruba ayrılmaktadırlar.

\subsubsection{Termoset Plastikler}

Termoset terimi, hem oda sicaklığında hem de daha yüksek sıcaklıkta çapraz bağlı yapıya dönüşebilen anlamına gelmektedir. Termoset plastiklerde polimer zincirleri arasında çapraz bağlar olması sebebiyle bu malzemeler her sıcaklıkta katı olarak bulunurlar [6]. Termoset plastikler; fenolik reçineler, furan reçineleri, aminoasitler, alkitler, doymamış asit poliesterleri, epoksi reçineler, poliüretanlar ve silikonlardır [7].

\subsubsection{Termoplastikler}

Plastiklerin bir alt grubu olarak sinıflandırılabilen termoplastikler isıtıldığında eriyebilen düz ya da dallanmış polimerlerdir. Çapraz bağların olmaması nedeniyle 1sıtıldığında polimer zincirleri arasındaki görece zayıf kuvvetler ortadan kalkar ve bu zincirlerin birbirleri üzerinden kolaylıkla kaymasıyla malzeme akışkan bir hal alır. Kullanılmış termoplastikler isı ve basınç uygulanmasıyla geri dönüştürülüp yeniden üretimde kullanılabilirler [6].

Termoplastikler genellikle her bir tür için kendisine has sıcaklıklar olan camsı geçiş sıcaklığ1 ve erime sıcaklığı arasında kullanışlıdır. Çünkü bu iki sıcaklık arasında kırılgan değildir ve tam bir sıv1 özelliği göstermezler [6]. Termoplastik türleri ve formül yapıları Şekil 1'de verilmekte, genel özellikleri ise alt başlıklar halinde özetlenmektedir.

PS

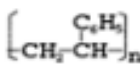

ABS

PVC

PMMA

POM

PET

PC

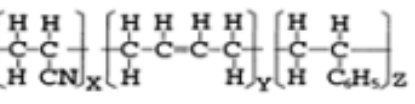

$\left.\mathrm{fCH}_{2}-\mathrm{CHCl}\right\}_{\mathbf{n}}$

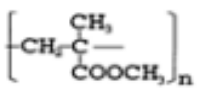

$\left\{\mathrm{CH}_{2}-\mathrm{O}\right\}_{\mathrm{n}}$
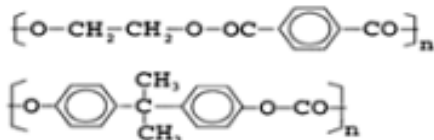

Şekil 1. Termoplastiklerin formül yapısı [8] 


\section{Akronitril Butadien Stiren (ABS)}

Üçlü kopolimer olup, mukavemeti ve tokluğu yüksektir. Dış ve kimyasal etkilere dayanıklıdır. Çekme mukavemeti 42-50 MPa, özgül ağırlığı $1,05-1,07 \mathrm{~g} / \mathrm{cm}^{3}$ 'tür. Elastisite modülü yoktur ve $75^{\circ} \mathrm{C}$ 'ye kadar olan isılara dayanırlar [9].

\section{Polikarbonat (PC)}

Polikarbonatlar kırılmaz ve dağılmaz camlar olarak yiyecek kapları ve son derece hafif gözlük camlarında kullanılır. Ayrıca polikarbonatların renklendirilebilme ve şekillendirilebilme kolaylıkları mevcuttur [6].

\section{Polietilen (PE)}

Petrol kimyasalların en önemlilerinden olan etilen molekülleri çeşitli tekniklerle birbirlerine eklenerek polimerleștirilebilir ve bunun sonucunda düşük molekül ağırlıklı mumlardan molekül ağırlığı çok yüksek olan kristal yapılı yüksek yoğunluklu polietilene kadar çok çeşitli ürünler elde edilebilir [6].

\section{Polietilen Teraftalat (PET)}

Polietilen Teraftalat'ın yoğunluğu 1,33-1,37 $\mathrm{g} / \mathrm{cm}^{3}$ 'dür. Maksimum kullanılabilir sıcaklığı $60^{\circ} \mathrm{C}$ 'dir. Orta sertlikte en çok kullanılan plastiklerden biridir. Açık veya hafif renkli, yarı saydam, suda yüzebilir özelliktedir ve erime sıcaklığı $250^{\circ} \mathrm{C}^{\prime}$ dir [5]. PET, termoplastikler arasında kristal yapıda, zayıf asitlere, bazlara ve çoğu çözücülere karşı dayanımı olduğu kadar, sağlamlık, sertlik, parlaklık ve yüksek darbe dayanımı gibi özellikleriyle de üstündür. PET'in gerilme dayanımı 8.000 psi olup bu değer 30.000 psi'ye çıkarılabilir. PET'in gaz geçirgenliği diğer plastiklerin çoğundan daha düşüktür. Şişe reçinelerinde normal olarak 2,5 ppm'den daha az artık Asetaldehit (AA) vardır. Aşırı AA seviyeleri içecek tadını etkiler [9].

\section{Polipropilen (PP)}

Polipropilen genel olarak polietilenle benzerlik gösterir ve aynı zamanda ucuzdur. Yoğunluğu
0,90-0,92 $\mathrm{g} / \mathrm{cm}^{3}$ arasında değişmektedir. Maksimum kullanılabilir sıcaklığı $135^{\circ} \mathrm{C}^{\prime} \operatorname{dir}[6]$.

\section{Polistiren (PS)}

Polistiren, petrol ürünü olan sıv1 stirenin polimerizasyonu ile elde edilmektedir. Yoğunluğu 1,03-1,06 $\mathrm{g} / \mathrm{cm}^{3}$ arasında değişmektedir. Maksimum kullanılabilir sicaklığ $\quad 70^{\circ} \mathrm{C}$ 'dir. Polistiren'in en tanınmış formu olan Styrofoam (köpük polistiren) Polistiren'den 30 kat daha hafiftir [6].

\section{Polimetil Metakrilat (PMMA)}

Polimetil metakrilat, camın yarısı kadar ağırlığa sahiptir, kırılmaz, daha kolay çizilir ama çizilmeyi engelleyen kaplamalarla bu sorun ortadan kolaylıkla kaldırılabilir. Işığı daha fazla iletmekte ve düşük sıcaklıklarda üretilmektedir. Sert bir malzeme olmasına rağmen $100^{\circ} \mathrm{C}$ 'de kısa sürede yumuşar ve istenilen şekle sokulabilecek hale gelir [6].

\section{Polivinil Klorür (PVC)}

PVC dünyada ilk kullanılan termoplastiklerden birisidir. PVC'nin monomeri etilenden (\%43) ve klordan (\%57) elde edilen vinil klorürdür. Yoğunluğu 1,32-1,42 $\mathrm{g} / \mathrm{cm}^{3} \quad$ arasında değişmektedir. Maksimum kullanılabilir sıcaklığı $70^{\circ} \mathrm{C}$ 'dir. PVC ürünleri genelde sert (rijid), yumuşak (soft) olmak üzere iki ana gruba ayrılır [9]. PVC'nin en önemli avantajı, çok çeşitli katkı maddeleri ile olan uyumudur. İçindeki klor atomları sayesinde alev alması kendiliğinden önlenir. Mükemmel elektrik yalıtımı sağlar ve kablolarda elektrik yalıtımı için kullanılır. Kuvvetli olması ve hava koşullarına olan dayanımı sebebiyle ideal bir yapı malzemesidir. Saydam ve renkli, sert ve esnek formülasyonları arasındaki rahat geçişi çok sık kullanılmasını sağlamıştır. Ayrıca, yüksek performansı ve ucuz maliyeti sebebiyle otomobil sektöründe sıça kullanılmaktadır [6].

\subsection{Plastiklerin Kullanım Alanları}

Günümüzde plastikler, ahşap, kağıt, metal, cam, 
pamuk, yün, ipek ve kauçuk gibi pek çok doğal ürünün yerini almış ve insan hayatının vazgeçilmez bir parçası haline gelmiştir. Plastiklerin çeşitli şekillerde işlenebilme özelliğinin yanında maliyet avantajları da teknolojik gelişmelerin çoğunda hayati öneme sahip olmalarını sağlamıştır. Elektrik ve elektronik sanayinde de plastiklerin kullanılmasının başlıca nedenleri; daha iyi tasarımlara imkân verebilmeleri, olağanüstü yalıtım özelliğine sahip olmaları, parçaların mümkün olan en küçük boyutta imal edilebilmesi, montaj kolaylığı ve uygun ve hafif bir depolama ortamı sağlamalarıdır [1].

Dünya plastik tüketimini yönlendiren sektörlerin başında ambalaj ve inşaat sanayi gelmektedir. Son yıllarda ise plastik kullanımı otomotiv sektöründe yaygınlaşmaya başlamıştır [1]. Çizelge 1 'de bu plastiklerin dönüşüm numaraları ve kullanım alanları verilmiştir [5].

\subsection{Dünya Plastik Endüstrisi}

Dünya'da büyük bir pazarı bulunan plastik ve plastik ürünlerinin başlıca üretici ve tüketicileri Kuzey Amerika, Batı Avrupa ve Güneydoğu Asya ülkeleri olup (Şekil 2), İspanya, İngiltere; İtalya ve Fransa gibi gelişmiş Batılı ülkelerde bu oran son derece düşüktür. Avrupa'nın en büyük ikinci sektörü olarak ön plana çıkan kimya endüstrisinin alt kolu olan plastik sektöründe yaklaşık 1,1 milyon kişi çalışırken, ancak 70 bin kişi plastik üretiminde çalışmaktadır. Batı Avrupa plastik sektörü yıllık cirosu yaklaşık 130 milyon Euro'ya ulaşmaktadır. Aynı zamanda, plastik imalatı sektörü yıllık yaklaşık 700 milyon Euro Ar-Ge harcaması yapmaktadır $[10,11]$.

\subsection{Türkiye Plastik Endüstrisi}

Ülkemizde; plastik işleyen firmaların önemli bir bölümü (yaklaşık \% 66), Şekil 3'de görüldüğü gibi

Çizelge 1. Plastiklerin kodlamaları özellikleri ve kullanım alanları [5].

\begin{tabular}{|c|c|c|c|}
\hline Dönüsüm No & Kısaltma & Polimer ismi & Kullanum \\
\hline & PETE, PET & Polietilen Teraftalat & $\begin{array}{l}\text { Polyester fiberler, film, elyaf, kōpük } \\
\text { sişe, katı cisim }\end{array}$ \\
\hline & YYPE & $\begin{array}{l}\text { Yuksek yoğunluklu } \\
\text { polietilen }\end{array}$ & $\begin{array}{l}\text { Taşumaya elverişli kapları yapunı, } \\
\text { çeşitli şş̧eler, çantalar, oyun alanı } \\
\text { malzemeleri }\end{array}$ \\
\hline & PVC & Polivinil klonür & $\begin{array}{l}\text { Cit ve parmaklik malzemeleri, } \\
\text { yiyecek dışı şişeler }\end{array}$ \\
\hline & DYPE & $\begin{array}{l}\text { Duşuk yoğunlukłu } \\
\text { polietilen }\end{array}$ & $\begin{array}{l}\text { Sera örtusĭ, film, ambalaj, elektrik } \\
\text { sanayi }\end{array}$ \\
\hline & PP & Polipropilen & $\begin{array}{l}\text { Plastik șişe, elektrik sanayi, mutfak } \\
\text { esyası }\end{array}$ \\
\hline & PS & Polistiren & $\begin{array}{l}\text { Oyuncak, video kaset, tepsiler, } \\
\text { yalitm malzemeler }\end{array}$ \\
\hline & Diger & $\begin{array}{l}\text { Alkrilik } \\
\text { polikarbonat, naylon } \\
\text { dahil diger plastikler }\end{array}$ & \\
\hline
\end{tabular}




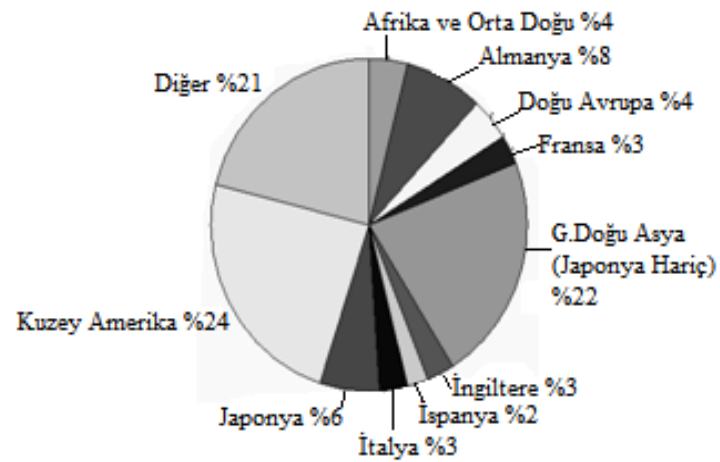

Şekil 2. Plastik tüketiminin ülkelere göre dağılımı [12]

İstanbul ve civarında yer almaktadır. Sektörde kullanılan işleme makinelerinin \%80-90'1 ülke içinde üretilen makinelerdir. Makine üreten firmaların bir bölümünün teknolojik düzeyi oldukça yüksek olup bazı firmalar üretimlerini, Batı ülkeleri dahil, pek çok ülkeye ihraç edebilmektedir. Plastik işleyen firmaların hemen hemen tümünün kendi kalıp üretim atölyeleri bulunmaktadır.

Türk plastik sanayisinin dünya plastik sektörü içindeki payı \%1,6 düzeyindedir. Yılda 3,7 milyon ton işleme kapasitesi ile $\mathrm{AB}$ ülkeleri içinde 6. sırada bulunan plastik sektörü, 2005 yılı sonunda 12,5 milyar dolarlık üretim değeri ile toplam GSMH içinde \% 4 pay almıştır. 2005 yılında 1,7 milyar dolarlık doğrudan ve 3 milyar dolarlık dolaylı ihracat ile kimyasallar sektöründe birinci ihracatçı sektör konumundadır [12].

Türkiye'de 1960'lı yıllara kadar uzanan plastik sektörü, özellikle 80'li ve 90'lı yıllarda hızlı bir büyüme eğilimine girmiştir. Ancak, sektörün hem mikro hem de makro ölçekte vizyon ve stratejik planlama eksikliğinden dolayı bir daralma ile karşı karşıya kaldığı ve plansız büyümenin sancılarını yaşamaya başladığı görülmektedir. Özellikle, aynı işi yapan birçok firmanın sektörde faaliyet göstermesi çok şiddetli bir maliyet odaklı rekabete neden olmaktadır [11]. Türkiye plastik sektörü, sahip olduğu avantajlarla rekabet gücü yüksek bir bölgesel oyuncu niteliğine dönüșme firsatına sahiptir.

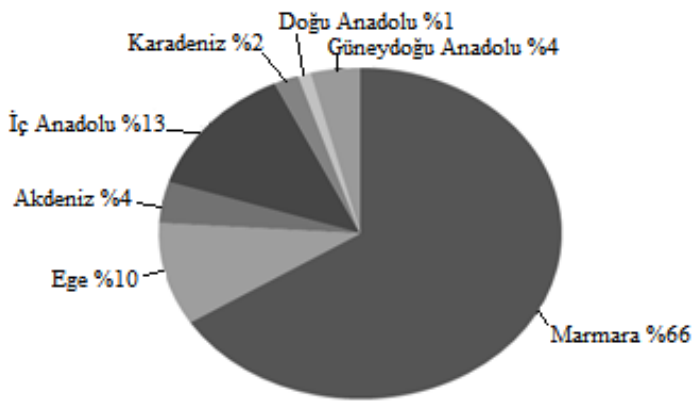

Şekil 3. Plastik firmalarının bölgesel dağılımı [13]

Türkiye, halen 44-50 kg olan kişi başına plastik tüketimi dünya ortalamasının üzerinde olmasına rağmen gelişmiş ülkelerdeki $100 \mathrm{~kg}$ rakamıyla karşılaştırıldığında önemli bir potansiyele ve büyümenin süreceğine işaret etmektedir. Mevcut büyüme hızının korunması halinde Türkiye'nin; 2010'lu yıllarda Avrupa ve Avrasya'nın üçüncü büyük plastik işlenen ülkesi olacağ1 değerlendirmesi yapılmaktadır [9].

8. plan döneminde yılda ortalama $\% 8$ büyüme hızı ile \%150 artış gösteren ve 1,5 milyon ton'dan 3,7 milyon ton'a çıkan plastik isleme kapasitesinin, 2006-2013 döneminde yılda ortalama \%15 büyüyerek 11,5 milyon ton'a çıkması ve $A B$ ülkeleri içinde 3. büyük plastik isleme kapasitesine erişmesi beklenmektedir. 2013 yılında plastik sektörü 5,2 milyar dolar doğrudan ve 12,5 milyar dolar da dolaylı olmak üzere toplam 17,7 milyar dolar ihracat hacmine ulaşacağ 1 öngörülmektedir [12].

\subsection{Plastik Atıklar}

Plastik, dünyanın en değerli doğal kaynağı, petrolden üretilir. Plastik genellikle ambalaj malzemesi olarak kullanılır ve çöpe gider. Diğer bir değişle çöp dağlarının 1/3'ü paketleme malzemesinden kaynaklanır. Plastikler, sonsuza dek çöp olarak kalır, yani hiç bir zaman doğaya geri dönmez. Günümüzde geri kazanılmış plastikten çöp torbasının yanı sıra bahçe çitleri, çiçek saksıları gibi uzun ömürlü tüketim malzemeleri yapılır. Plastik malzemeler ucuzluk, dayanım, kolay işlenebilme, hafiflik ve temizlik 
gibi avantajları ile kullanımı oldukça yaygın olan malzemelerdir. Plastikler ambalaj ve paketleme sanayi uygulamalarında kullanım ömürlerinin kısa olmasından dolayı, üretildikten çok kısa bir süre sonra katı atık problemi oluşturmakta, doğa koşullarında parçalanmama ve bozunmadan kalma gibi dezavantajlara sahiptir. Toplam plastik atıklar içerisinde en büyük pay $\% 40$ ile ambalaj atıklarınındır ve bunların büyük çoğunluğu evsel atıklar içerisinde bulunmaktadır. Bunun yanında plastikler, paketleme ve ambalaj miktarını azaltmaktadır. Yani $1 \mathrm{~kg}$ plastik malzemeyle $27 \mathrm{~kg}$ sıvı ambalajlamak mümkün iken aynı miktarda Sıv1 için $1,5 \mathrm{~kg}$ alüminyum, $4 \mathrm{~kg}$ çelik veya 13-14 kg kadar cam malzemeye ihtiyaç vardır. $\mathrm{Bu}$ da doğal kaynakların korunması ve tasarruf edilmesi anlamına gelmektedir. Kağıtla karşılaştırıldığında, plastik malzeme aynı işi görecek kağıt malzemeden çok daha az toplam üretim enerjisi gerektirir [14].

Genellikle plastik atıklar, tüketiciler tarafindan kullanım sonrası veya endüstride üretimi esnasında oluşur. Ekonomik öneme sahip yaklaşı 50 tip plastik mevcuttur. Toplam plastik tüketiminin yaklaşık \%60'ını PE, PET, PP, PS ve PVC gibi geleneksel polimerler kapsar. Hem yaşadığımız çevreyi, hem dünyamızı ve enerji kaynaklarımızı korumak, hem de üstün özelliklerinden faydalanmaya devam etmek için plastik malzeme geri dönüşümünü sağlamak gerekli ve önemlidir. Plastiğin geri dönüşümü her geçen gün biraz daha artmaya başlamış ve \%30 hatta bazı plastiklerde $\%$ dönüşüm sağlanmıştır. Belediyelerce toplanan çöpler ihaleye çıkarılmakta, ihaleyi kazana firmalar çöpleri ayıklayıp ekonomik değeri olan malzemeleri ait oldukları sektöre satmaktadır. Plastikler de aynı kanalla toplanmakta ve daha az değerli olan ikincil malzemelere dönüştürülmektedir [14].

\subsubsection{Plastiklerin Geri Dönüșümü}

Değerlendirilebilir atıkların kaynağında ayrı toplanması, bu atıkların katı ayırma atık tesislerinde işlenerek özelliklerine göre daha homojen gruplara sinıflandırılması, atıkların bu şekilde tekrar kullanılabilecek ve ikincil hammadde haline getirilebilecek nitelikte elde edilmesi "geri kazanım" olarak tanımlanır. Geri kazanılamayan ve her sene milyonlarca tona ulaşarak yoğunlaşan plastik dağların yaratacağ sonuçlar ortadadır. Toplam plastik tüketiminin yaklaşık \%60'ını PE, PET, PP, PS ve PVC gibi geleneksel polimerler kapsar. Hem yaşadığımız çevreyi, hem dünyamızı ve enerji kaynaklarımızı korumak, hem de üstün özelliklerinden faydalanmaya devam etmek için plastik malzeme geri dönüşümünü sağlamak gerekli ve önemlidir.

Plastik atıkların değerlendirilmesi için gereken birkaç basamak vardır. Bunlardan ilki plastik atıkların toplanma işlemidir. Daha sonra da plastik atıkların ayırma işlemine geçilmektedir [14]. Ayırma türlerinden ilki, farklı tür plastiklerin değişik yoğunluklara sahip olması özelliğinden yararlanılarak yüzdürme-batırma ile ayırma yöntemidir [15]. İkinci yöntemi elle ayıklama, hidrosiklon ile ayırma, hava ile sınıflandırma, depolimerizasyon, seçimli çözündürme ve lazer taraması gibi değişik türdeki ayırma teknikleri oluşturur [16]. Son yöntem ise, flotasyon ile ayırmadır. Gravite veya diğer yöntemlerle ayrılamayan ve çoğu doğal olarak hidrofobik (suyu sevmeyen) olan plastiklerin bazılarının yüzeyine adsorbe olan kimyasallar ile yüzey özellikleri değiştirilmekte ve hidrofilik (suyu seven) özellik kazandırılarak batması ve hidrofob olan diğer plastik türünün oluşturulan hava kabarcıklarına tutunarak yüzmesi ve seçimli olarak ayrılması sağlanır [17].

Yüzey özelliklerine bakılacak olursa, plastiklerin hidrofobiklik dereceleri sırası ile büyükten küçüğe doğru $\quad$ PS $>$ ABS $>$ PC $>$ PET $>$ PMMA $>$ PVC $>$ POM şeklinde sıralanır [8]. Bu sıralamaya göre, $P E T$ ve PVC'nin hidrofobiklik dereceleri birbirine oldukça yakındir. $\mathrm{Bu}$ nedenle de, flotasyon uygulamalarında plastikleştirici reaktifler kullanarak yüzey özelliklerinin değiştirilmesi gerekmektedir. Bunun yanı sira plastiklerin yoğunluk aralıkları arasında da yüksek farklar bulunmamaktadır. Plastiklerin yoğunluk farklılıklarının göreceli karşılaştırılması Şekil 4'te verilmiştir. Şekilden görüldüğü üzere, plastiklerin yoğunluk aralıkları birbirlerine oldukça yakındır ve $0,9 \mathrm{~g} / \mathrm{cm}^{3}$ ile $1,427 \mathrm{~g} / \mathrm{cm}^{3}$ arasinda değişmektedir. Yoğunlukları büyükten küçüğe 
doğru, $\mathrm{POM}>$ PVC $>$ PET $>$ PUR $>$ PC $>$ PA $>$ $\mathrm{PS}>\mathrm{ABS}>\mathrm{PE}>\mathrm{PP}$ şeklindedir [18].

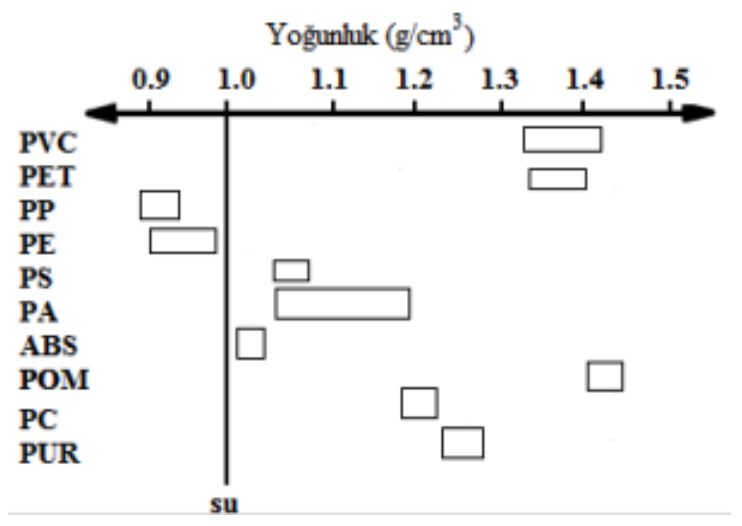

Şekil 4. Plastiklerin yoğunluk aralıkları [18]

\subsubsection{PET ve Geri Dönüşümü}

Geri kazanılmış PET'lerden halı tabanları, uyku tulumları, yastık, yorgan, giysilerdeki yalıtım maddesi, oto parçaları, boya firçaları, cankurtaran yastıkları, torbalar, posta kutuları, piknik masaları, çitler, yürüyüş botları, çift bölmeli kovalar, lazer toner kartuşu ve kayışlar gibi malzemeler üretilmektedir. PET'ten oluşan tekrar doldurulabilir kapların kullanım alanı gittikçe genişlemiştir [5].

Avrupa Birliği üyesi her devlette, gida ile temas eden geri dönüştürülmüş plastiklerin kullanılmasını düzenleyen ulusal yasalar bulunmaktadır. Belçika ve Fransa gibi bazı üye devletlerde geri dönüştürülen maddelerin gıda ile temas eden plastiklerde kullanılabilmesi için geri dönüştürme sürecinin önceden onaylanması gerekmektedir. Gıda ile temas eden plastiklerde geri dönüştürülmüş maddelerin kullanılması en az iki Avrupa ülkesinde (İspanya ve İtalya) genel olarak yasaktır.

Gıda ambalajında kullanılan tüm PET şişelerin geri dönüşümünü değerlendirmek için, polimerde beklenilen maksimum kirlenme konsantrasyonunun gerçekçi tahmin edilmesi gerekmektedir. Geri dönüştürülmüş PET'ten yapılmış yiyecek kaplarında yiyecek dışı kirlenmeden etkilenme tartışılmış ve gıda için kullanılacak uygun kapların üretilmesi amaciyla FDA (Amerikan Gıda ve İlaç Dairesi) tarafından ilişkiyi açıklayabilecek testler geliştirilmesi önerilmiştir [5].

\subsubsection{PVC ve Geri Dönüşümü}

Genel olarak toplum ve karar alıcı merciler PVC kaynaklı çevresel problemlere geri dönüşümün teknik bir çözüm olduğunu kabul etmekteler. Bu durum, özellikle gelişmiş geri dönüşüm politikalarına sahip Danimarka, Almanya, Hollanda ve Amerika gibi ülkelerde mevcuttur. Gerçekte, Greenpeace dünyanın başlıca PVC tüketim alanlarında geri dönüşümünün tüketimine oranlandiğında yüzde birden daha düşük miktarlarda olduğunu bulmuştur. Bağımsız bir araştırmaya göre PVC atıklarının \%75-80'inin orta ve uzun vadede geri dönüşümün bir alternatif bile olamayacağı belirtilmiştir. $\mathrm{Bu}$ yüz binlerce ton PVC'nin yakın bir gelecekte büyüyen bir bertaraf problemi yaratmaya doğru ilerlediğini anlamına gelmektedir. Greenpeace'in PVC endüstrisinin önde gelen kuruluşlarını PVC'nin geri dönüştürülebilir olduğuna inandırma çabaları, bu plastik madde üzerinde yapılan testlerde söz konusu olayın imkansız olduğunu kanıtladığı için sonuç vermemiştir. Bunun nedeni, toplama işleminin zor ve pahalı olması ve geri dönüştürülmüş ürün piyasasının direkt ucuz olan orijinal PVC ürün piyasasına göre daha küçük bir piyasa olmasıdır.

PVC'nin geri dönüştürme işleminde başlıca problem, ham PVC'nin yüksek oranlarda klor içermesi (polimer ağırlığının \%56'sı) ve istenilen materyal kalitesinin elde edilebilmesi için polimere eklenilen çok fazla tehlikeli olan katk1 maddeleridir. Katkı maddelerinin ağırlığı PVC ürün ağırlığının \%60'ını oluşturabilmektedir. Tüm plastikler içinde PVC en çok katkı maddesi içeren maddedir. Sonuç olarak, PVC'nin diğer plastiklerden ayrıştırılması ve mekanik geri dönüştürme işleminden önce türlerine ayrılması gerekmektedir. $\mathrm{Bu}$ nedenle PET şişe geri dönüşümü yapanlar PVC şişelerinin karışımlarını kirletmediğinden emin olmalıdırlar [19]. 


\subsection{Geri Kazanılmış Plastiğin Ekonomisi}

PET'in kimyasal geri dönüşümünün maliyeti çok yüksek olup yılda 50.000 tonun üzerinde bir üretim söz konusudur. 2000 y1lından 2008 y1lına kadar plastik şişelerin fiyatları $50 €$ €/ton'dan $500 € /$ ton'un üzerine çıkmıştır [20]. PET fiyatları 2009 y1lı itibariyle Avrupa'da $800 € /$ ton, Bat1 Avrupa'da 1165-1290 €/ton, Doğu Avrupa'da ise $890-995 € /$ ton olmuştur. Üretim, belirgin bir şekilde 2008'in ikinci yarısından 2009'un başlarına kadar düşmüş, bazı üreticiler düşük talep ve fiyatlardan dolayı üretimi durdurmuşlardır. PVC fiyatları 2009 Şubat ortasından beri Çin'de 700 \$/ton'dur. Fiyatlarda devamlı iniş çıkışlar kaydedilmiştir. Türk malı PVC ise 2010 yılı itibari ile $1500 \$$ /ton fiyattan satılmaktadır [21].

PP fiyatlarında ise 2005 yllında yüksek belirsizlik yaşanmıştır. Fiyatlardaki bu değişim, arz-talep dengesi dışında petrol fiyatlarının maliyetler üzerindeki etkisinden kaynaklanmıştır. PP fiyatları Ekim 2005'te 1.400 \$/ton seviyelerindeyken 2006 ortasında \%14'lük bir gerileme kaydedip 1.200 \$/ton'a düşmüştür [22]. Son iki aylık dönemde ise Türk malı PP, 2050 \$/ton civarlarında fiyatlarla alıcı bulmaktadır. 2010 yılı itibari ile Türk malı alçak yoğunluklu PE'nin fiyat aralığı 2180-2200 \$/ton, yüksek yoğunluklu PE'nin fiyatı ise 2120 \$/ton civarında olmuştur [23].

\subsection{PET ve PVC Ayırımı ile İlgili Flotasyon Çalışmaları}

$\mathrm{Bu}$ başlık altında özellikle yüksek oranlarda kullanım alanları olan PET ve PVC'nin geri dönüşümünde flotasyon bazlı yapılmış çalışmalardan özetler derlenmiştir.

1999 yılında Drelich ve arkadaşlarının yapmış olduğu araştırmaya göre sodyum hidroksitin, güçlü alkali çözeltilerinin PET'in hidrofobik özelliğini yok ederek PVC'nin PET'ten ayrılmasına imkan sağladığ1 görülmüştür. Reaktif olarak $15-30 \mathrm{mg} / \mathrm{L}$ Rhodasurf 91-6 C9-11 Etoksilat alkol kullanılmıştır. $\quad 15-30$ dakika $75^{\circ} \mathrm{C}$ 'de alkali muamelesi sayesinde PVC, PET'ten ayrılmaktadır. $\mathrm{Bu}$ araştırmada sodyum hidroksitin PET'i hidrofilik yaparken, PVC'nin hidrofobik özelliğini çok etkilemediği görülmektedir. PET ve PVC karışımına plastikleştirici eklendiğinde yüksek sıcaklıkta PVC parçacıklarının hidrofobikliğini yüksek oranda artırdığı, PET parçacıklarını ise çok az etkilediği görülmüştür. Plastikleștirici olarak Diisodil Ftalat kullanılmıştır. Alkali ile 30 dakika muameleden sonra PVC ve PET'lerin her ikisi de 5-40 mg/L sicak plastikleştirici ile 30 dakika kıvamlandırılmış, ardından süzülüp kurutulmuştur. PET'in temas açısı sabit kalırken, PVC'ninki 15-18 ${ }^{\circ}$ den $24-28^{\circ}$ ye çıkmıştır. Bu uygulamalar sırasında sıcaklığın önemli bir etken olduğu görülmüştür. S1caklıkla birlikte plastikleştiricinin PVC üzerinde etkinliğinin arttığı tespit edilmiştir. Dietilen Glikol Dibenzoat kullanılarak yapılan deneylerde 3 dakikadan sonra yüksek verimle (\%95'den fazla) PET-PVC ayırımı yapılabilmiştir. $\mathrm{Bu}$ uygulama sayesinde \%93-95 arasinda PET elde edilip \%98-100 oranında PVC ayrılmıştır [24].

1999 yılında Shen ve arkadaşlarının yapmış olduğu çalışmada; hidrofilik yapan yüzey aktif maddelerin etki mekanizması araştırılmıştır. Seçimli hidrofilik yapmanın bir yolu kimyasal kıvamdır. $\mathrm{Bu}$ ise, reaktiflerin plastiklerin yüzeylerine adsorbe olması, katı-sıvı arası yüzey hidrofobikliğini azaltması esasına dayanmaktadır. Seçimli hidrofilik prosesi, farklı plastiklerin değişik sslanabilme şartları sayesinde gerçekleşmektedir. Şekil 5'te yüzey aktif maddelerle polimerlerin adsorpsiyon mekanizması görülmektedir. Adsorpsiyon ile ilgili önerilen mekanizma şu şekildedir:

a) Plastiklerin polimer zincirlerinin lateral grupları polar olmayan karbon ve hidrojen içermektedir. $\mathrm{Bu}$ plastik yüzeyindeki moleküller ile bastırıcı etkideki moleküller arasındaki fiziksel etkileşimi açıklar. Bu reaksiyonlar itici Van-DerWaals kuvvetleri ve hidrojen bağlar ile olmaktadir.

b) Bazı polimerler oksijen, azot, klor gibi atomlara sahip olan polar lateral gruplar içermektedir. $\mathrm{Bu}$ lateral gruplar bastırıcı moleküller ile Dipol-Dipol Van-Der-Waals ve Lewis asit-baz kuvvetleri ile etkileşim halindedir. 
c) Plastik yüzey ve bastırıcı moleküller arasındaki kimyasal bağlanma çok nadirdir, çünkü plastikler düşük yüzey enerjilerine sahip, flotasyon prosesi boyunca kimyasal olarak neredeyse sabittir.

d) Minimum serbest yük taşıyanlar dahil olmadı $\breve{g ̆}_{1}$ için elektrostatik etkileşimler pek az gerçekleşir [18].

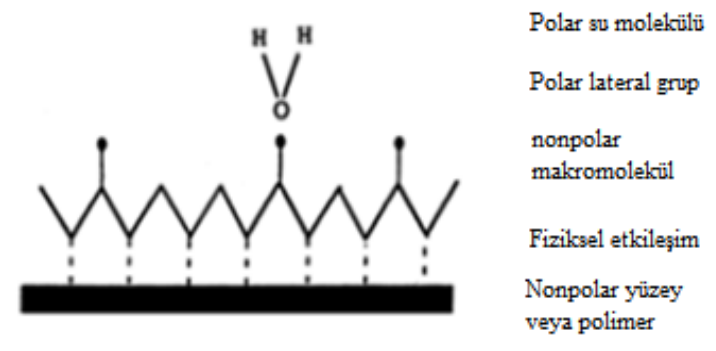

Şekil 5. Yüzey aktif maddelerle polimerlerin mekanizmasi [18]

2000 yılında yapılan bir çalıșmaya göre, PET ve PVC'nin hidrofobik olduğu, ön muamele sayesinde birisini hidrofilik yapmanın mümkün olduğu belirlenmiştir. Reaktiflerin içerisinde lignosülfonat, tannik asit en çok kullanılmış ve plastiklerin üzerindeki bastırıcı etkisi araștırılmış olanlardandır. Deneyler esnasında musluk suyu kullanılmıştır. Dolayısıyla bastırıcı etki suyun kalitesi ile ilgilidir. Saf suda yapılmıș olan çalışmada reaktifin bastırıcı etkisi görülmemiştir. Reaktifle muamele neticesinde PVC'nin temas açısında değişim olmazken PET'in temas açısının $10^{\circ}$ düștüğü ve neticesinde hidrofilik olduğu gözlemlenmiştir [25].

2000 yılında yapılan başka bir araştırmada; flotasyonun en ucuz ve benzer yapıdaki tanelerin ayrılması için en uygun metot olduğu belirtilmiştir. Buna göre yüzey aktif madde olarak Kalsiyum Lignin Sülfonat, köpürtücü olarak MIBC kullanıldığında PVC'yi PET'ten ayırmak mümkün olmuştur. $\mathrm{Bu}$ reaktifler kullanıldığında kıvam için ideal zaman 60 dakika'dır. En iyi ayırma boyutu, $-3,36+1,70 \mathrm{~mm}$ olarak saptanmıștır. Parça büyüklüğü arttıkça seçicilik artmakta fakat kazanım düşmektedir [17].
2001 yılında Shen ve arkadaşlarının yapmıș olduğu çalışmalara göre, plastiklerin yüzebilirliği sadece kimyasal reaktiflerden değil yerçekimi faktöründen de etkilenmektedir. Buradan yola çıkılarak, parçacık büyüklüğünün kontrolü sayesinde plastik karışımlarının seçimli olarak ayrilabileceği gösterilmiştir [26].

2002 yılında Shen ve arkadaşlarının yapmış olduğu çalışmalara göre, POM, PVC, PET, PMMA, PC, PS ve ABS'nin yüzebilirlikleri Alkil Etoksilat noniyonik yüzey aktifleştirici madde varlığında azaldığı görülmüștür. Ancak, her birisinin yüzebilirliği farklı azalmış, POM $<$ PVC $<$ PMMA $<$ PET $<$ PC $<$ ABS $<$ PS şeklinde yüzebilirlikleri sıralanmıştır. Alkil Etoksilat'ın bastırıcı olarak etki etmesinin nedeni, sıv1 yüzey gerilimini düșürmesidir. Düşük yoğunluklu daha fazla temas açısına sahip daha düşük şekil özelliklerine sahip olan plastiklerin daha yüksek yüzebilirliklere sahip oldukları saptanmıștır. Bu çalışmada; verimin \%99, içeriğinin \%97'den fazla olabildiği gözlemlenmiştir [8].

2003 yllında Pascoe ve O'Connell'ın yapmış olduğu çalışmalara göre, yakma yöntemi plastik yüzeyine oksijenli fonksiyon grubu ilavesinde sonuç vermiştir. PVC'nin yumuşama noktasının üzerinde $\left(75^{\circ} \mathrm{C}\right)$ hızlı bir şekilde hidrofobik yüzeye sahip olduğu ancak PET'in ise hidrofilik kaldığ 1 gözlenmiştir. Temas açısının yumuşama noktasından sonra $\mathrm{pH}$ ile etkili bir şekilde değiştiği saptanmıştır. PVC'nin sıfır yük noktası $\mathrm{pH}$ 4'de elde edilmiştir. PET ve PVC'nin $\mathrm{pH} 4$ ile 7 arasında köpürtücü kullanmadan yüzebildiği görülmüştür [27].

2006 y1lında Takoungsakdakun ve Pongstabodee'in yapmış olduğu çalışmalara göre, POM, PET ve PVC karışımından 1slatıcı madde olarak $500 \mathrm{mg} / \mathrm{L}$ kalsiyum lignosülfonat, $\mathrm{pH} 7$ ve $220 \mathrm{~mL} /$ dak hava hızı şartlarında ayrılmıștır. PET'in PVC'den ayrılması için $\mathrm{pH} 5,8$ ve $180 \mathrm{ml} /$ dak hava hızı şartlarında $500 \mathrm{mg} / \mathrm{L}$ Kalsiyum Lignosülfonat ve $\% 0,01$ oranında $\mathrm{Al}_{2}\left(\mathrm{SO}_{4}\right)_{3}$ ilavesiyle flotasyon gerçekleştirilmiştir. PET'in sıfir yük noktası $\mathrm{pH}$ 6,5; PVC'nin ise pH 5,8'dir. Sıfır yük noktası şartları sağlandığında PVC PET'ten ayrilmaktadır [28]. 2007 yılında 
İstanbul Teknik Üniversitesi Maden Mühendisliği Bölümü'nde yapılan çalışmalarda; PET'in PVC'den seçimli olarak ayrılması için Dietilen Glikol Dibenzoat kullanılarak gerçekleştirilen flotasyon deneyleri sonucunda optimum koşullar pH 4, 1000 g/t Dietilen Glikol Dibenzoat, 5 dakika kıvam süresi ve 3 dakika köpük alma süresi olarak belirlenmiştir. İki kademede gerçekleştirilen kolon flotasyonu deneyi sonunda, \%42,1 oranında \%100 saflıkta PET konsantresi, \%84,3 PET kazanma verimiyle elde edilmiştir [29]. 2009'da ki diğer bir çalışmada ise; $50 \mathrm{~L} / \mathrm{sa}$ hava, $\mathrm{pH} 8$ 'de ve $25 \mathrm{~g} / \mathrm{t}$ Lignin Alkali kullanılarak yapılan deneyler sonucunda PET, \%99,93 içerik ve \%99,8 verim ile geri kazanılmıştır [30].

2010 y1lında Kılıç'ın yapmış olduğu pilot ölçekli deneylerde $\mathrm{pH}$, besleme boyutu, pülpte katı oranı, reaktif miktarı, kolon yüksekliği hava basıncı, sicaklık, hava hızı gibi parametreler incelenmiştir. Sonuç olarak pH 10'da, $-3,36+2,0 \mathrm{~mm}$ besleme boyutunda, $25 \mathrm{~g} / \mathrm{t}$ Lignin Alkali, $5000 \mathrm{~g} / \mathrm{t}$ MIBC, \%17 PKO'da, 2,5 Bar hava basincında, 2,6 cm/sn hava hızında yapılan deneylerde \%95,6 içerikte, \%92,3 kazanma verimiyle PET yüzdürülerek elde edilmiş, \%99,4 içerikte \%90,1 kazanma verimiyle ise PVC batırılarak alınmıştır [31].

\section{KOLON FLOTASYONU}

Flotasyon kolonlarını diğer flotasyon makinalarından ayıran en önemli özellikler; mekanik karıştırıcısının bulunmaması, kabarcık üretecinin varlığı ve yıkama suyunun kullanımı olarak siralanmaktadır [31]. Sayilan bu farklılıkların kolona sağladığı en önemli avantajlar ise, üretilen konsantrenin kalitesi (tenörü) yüksektir. Düşük enerji tüketimi sağlar. Otomatik kontrol imkanı yüksektir. Kapladığı yüzey alanı düşüktür. Verilen hava debisi yüksek olduğundan dolayı işlem kapasitesi yüksektir. Yapımı ve dizaynı kolaydır. Yatırım ve bakım masrafları daha düşüktür. Zenginleştirilecek cevherin boyut aralığı oldukça yüksektir $(10 \mu \mathrm{m}-2,3 \mu \mathrm{mm})$. Klasik flotasyon hücrelerine göre avantajlarının yanında kolonun dezavantajları ise şunlardır; Kolonun bulunduğu yerin tavan yüksekliği oldukça fazla olmalıdır (13-14 metre) ve fazladan yıkama suyuna ihtiyaç duyulmaktadır [32]. Laboratuvar tipi kolon flotasyonu ünitesinin klasik flotasyon ünitesi ile mıkayeseli bir resmi Şekil 6'da verilmektedir.
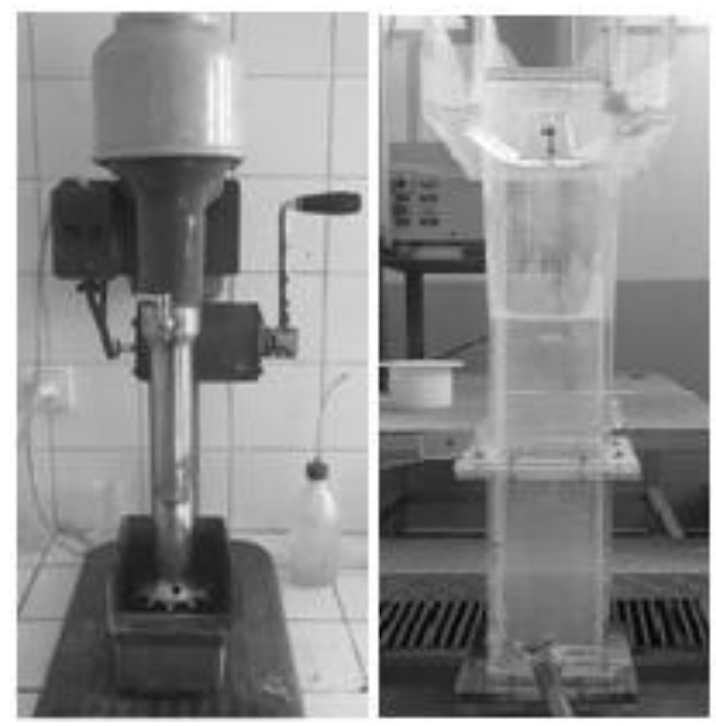

Şekil 6. Klasik flotasyon hücresi (solda) ve flotasyon kolonu (sağda) [31]

Flotasyon kolonları genelde çalışma ilkeleri aynı olmakla birlikte ikiye ayrılırlar;

- Klasik flotasyon kolonu

- Modifiye flotasyon kolonu.

$\mathrm{Bu}$ iki flotasyon kolonu arasındaki farklılıklar şu şekilde sıralanabilir;

- Modifiye kolonda köpük zonu yoktur,

- Klasik kolonda artık çıkışının debisi (Qa) ile besleme debisi $(\mathrm{Qb})$ arasındaki fark (Bias= Qa-Qb) pozitiftir. Diğerinde ise negatiftir,

- Klasik kolonda yıkama suyunu ilave etmek gerekir. Diğerinde ise zorunlu değildir,

- Modifiye kolon iri tanelerin zenginleştirilmesinde kullanılır [32].

\section{1 . Flotasyon Kolonunun Çalışma İlkesi}

Kolon dışında koşullandırılmış zenginleştirilecek mineral yaklaşık \%5-30 katı oranı ile besleme noktasından kolona beslenmektedir. Beslenen taneler, gravite etkisiyle zenginleştirme zonunda düşerken, kabarcık üreteci tarafından üretilen hava 
kabarcıkları yükselmeye başlar. Hava kabarcıklarıyla karşılaşan hidrofob parçacıklar arasında flotasyonun mikro olayları (çarpışma, yapışma vs.) gerçekleştikten sonra tane-kabarcık agregaları oluşur. Oluşan agregalar köpük zonunu geçer ve kolonun üst kısmından kolonu terk eder [33].

Yüzmeyen parçacıklar ise, kolonun tabanına doğru düşer ve kolonu terk eder. Yüzmeyen tanelerin konsantre içinde sürüklenmesini (hidrolik veya sıkışma yoluyla) önlemek için kolonun üst kısmından yıkama suyu ilave edilir. Sonuç olarak yüzmeyen parçacıklar ve bir kısım hidrofob parçacıklar temizleme zonundan zenginleştirme zonuna geri dönerler. Yıkama suyunun diğer bir etkisi de, köpük zonunun varlığını ve seviyesini ayarlamaktır. İlave edilen yıkama suyunun bir kısmı zenginleştirme zonuna geçer, geriye kalan kısmı köpük zonundan kolonu terk eder [33].

\subsection{Flotasyon Kolonunda Oluşan Zonların Tanımı}

Klasik flotasyon kolonunda, Şekil 7'de görüldüğü gibi 2 temel zon tanımlanır. Bu zonlar; kolonun alt kısmını oluşturan ve zenginleştirme olayının gerçekleştiği zenginleştirme zonu ve üst kısmında hava kabarcıklarının yoğun olarak bulunduğu köpük zonu olarak adlandırılır. Bu iki zon arasında farklı hava kabarcığı konsantrasyonu sebebiyle belirgin bir ara yüzey gözlenebilmektedir. Kolonda flotasyon prosesinin başarısı için bu özelliklerin iyi bilinmesi gerekir [33].

\subsubsection{Zenginleştirme Zonu}

Kolonun alt kısmını oluşturan ve flotasyonun mikro olaylarının (karşılaşma, çarpışma, yapışma, kopmama ve parçacık-kabarcık yükselmesi) gerçekleştiği zondur. Bu bölgede gaz tutunum yüzdesi \%10-20 arasındadır [34].

Pülp beslemesi, bu zonun hemen üstünden yapılır. Besleme içindeki mineral parçacıkları pülp ile inerken kolon dibinde hava üreteci tarafindan üretilen ve yükselen hava kabarcıkları ile karşılaşır [35]. Flotasyonun fiziksel mikro olayları hidrofob parçacıklar ile kabarcıklar arasında gerçekleștikten sonra kabarcık-parçacık agregaları köpük zonuna doğru yükselirler. Çoğunlukta olan hidrofil taneler bu zonun alt kısmindaki artık çıkışından kolonu terk ederler.

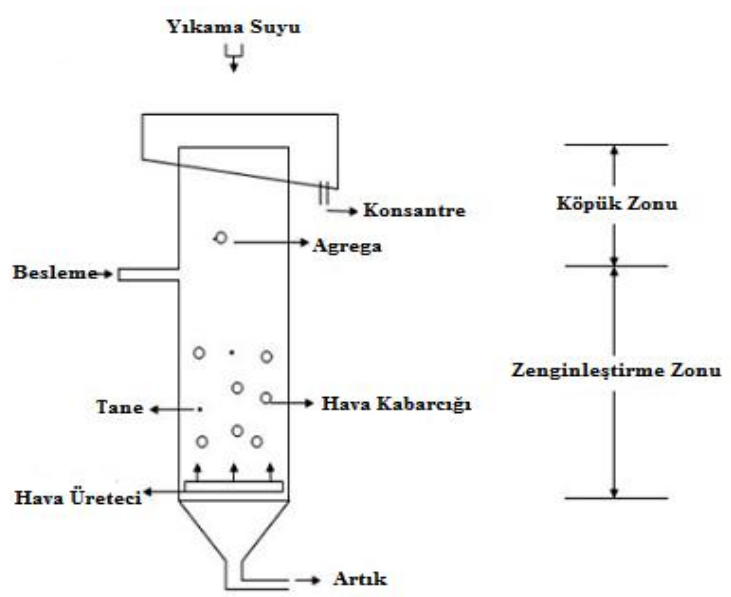

Şekil 7. Flotasyon kolonu zonları

Hava üreteçleri genelde poroz paslanmaz çelikten yapılır. Kauçuk veya filtre bezinden imal edilmiş hava üreteçleri de alternatif olarak kullanılabilir. Köpürtücü ilave edilen sulu ortamda $2 \mathrm{~mm}$ veya daha küçük çaplı hava kabarcığı veren hava kabarcığ1 üreteçleri tercih edilir [35].

Kolona verilen gaz debisi (Qg) ile kabarcık üreteci yüzey alanı (As)arasında bir oranlama düşünüldüğünde, gaz debisi arttıkça, kabarcık üreteci birim yüzey alana düşen hacimsel gaz miktarı ve kabarcık çapı da artar ve sonuç olarak belirli bir noktadan sonra verimin düştüğü görülür. Genelde endüstriyel ölçekte $4-40 \mathrm{delik} / \mathrm{cm}^{2}$ hava üreteçleri kullanılır. Qg/As oranı yaklaşık olarak $2-5,5 \mathrm{~cm} / \mathrm{sn}$ arasindadir [36].

Kolon içinde gravite etkisi ile düşen hidrofob bir tanenin, yükselen hava kabarcı̆̆ına yapışabilmesi ve yüzdürülmesi, flotasyonun temel mikro olaylarının sıralı bir biçimde gerçekleşmesine bağlıdır [32]. Yani, tane ile kabarcığın zenginleştirme zonunda karşılaşması, tane için yeterli serbest yüzeye sahip kabarcık ile tanenin çarpışması, tanenin kabarcığa yapışması ve tane-kabarcık agregasının dış kuvvetlere karşı 
yeterli direnci göstermesi sonucunda tane, yükselir ve kazanımı gerçekleşir [35].

\subsubsection{Köpük Zonu}

\%60-70 civarında gaz tutunumu olan ve konsantrenin yıkama suyu ilavesi ile yıkandığı bölgedir [33]. Gaz tutunumunun \%74'ten fazla olması, istenmeyen kabarcık birleşimine sebep olmaktadır [37]. Bu zonun yüksekliği arttıkça, konsantrenin tenörü artar fakat verimi düşer. Köpük zonunun toplam verim üzerine etkisi negatiftir. Köpük zonunun varlığı "Bias" değerine bağlıdır. Bias değeri negatif ise köpük oluşmaz [36].

\subsection{Flotasyon Kolonlarının Tasarımı}

Flotasyon kolonları, uzunluğu çapına göre yaklaşık 4-15 kat fazla olabilen silindirik veya kare kesitli prizma şeklinde, paslanmaz sactan veya pleksiglastan yapılan ünitelerdir. İnce veya normal boyutlu taneler için besleme, zenginleștirme zonunun hemen üst kısmından yapılır (Şekil 7). Laboratuar ölçekte genel olarak bir metre uzunluğunda (0,25-1 metre) olan köpük zonu, hemen besleme noktasının üst kısmından başlar. Zenginleştirme zonu uzunluğu, çeşitli parametrelere bağlı olarak önceden yapılmış modelleme programlarılla hesaplanır. Endüstriyel ölçekte köpük zonu 1-3 metre arasındadır. Yüzebilir parçacıkları kolonun üst kısmına taşıyacak olan hava kabarcıkları, kolonun alt kısmında bulunan hava üreteci (sparger) tarafından sisteme verilir. Hava üreteci, paslanmaz poroz metalden veya plastik boru-filtre bezinden yapılabilir. Flotasyon sırasında elde edilen konsantre, kolonun üst kısmından, artık ise alt kısmından alınır. Yıkama suyu köpük zonunun 3-4 $\mathrm{cm}$ üstünden veya içinden püskürtmeli olarak sisteme verilir. Ayrıca, ilave pompa kullanılarak artık akışını kolaylaştırmak mümkündür $[31,38]$.

\section{GENEL DEĞERLENDİRME}

Plastiklerin doğada uzun süre kalarak çevre kirliliğindeki ciddi tehlikelerden biri olması ve dünya plastik tüketiminin giderek artması, bu maddelerin geri dönüşümünü gündeme getirmiştir. Geri kazanımı üzerinde durulan en önemli iki plastik türü; PET ve PVC'dir. PVC'lerde bulunan katk1 maddelerinin çevreye zehirli gazlar ve hidroklorik asit karıştırma riskinden dolayı, bu zararları önlemek adına PET ve diğer plastiklerden ayrılması için çalışmalar yapılmaktadır. Plastiklerin yoğunlukları birbirine yakın olduğundan dolayı, gravite yöntemleri ile ayrılması söz konusu değildir, fakat yüzey özelliklerinden yararlanılarak PET ve PVC'den biri hidrofilik yapılıp batırılırken diğerinin yüzdürülerek köpükle alınması mümkündür. Doğal hidrofobik olan plastiklerden hidrofilik olması istenen plastiğin yüzeyi değiştirilmesi gerekir ve bu sebeple plastikleştirici reaktifler kullanılır.

Cevher hazırlama, zenginleştirme, atıklardan geri kazanım gibi konuların öneminin giderek yoğun olarak arttı̆̆ günümüzde; yaygın kullanım alanlarına sahip plastiler ve bunların geri kazanımı konularındaki çalışmalar önem taşımaktadır. Bu noktadan hareketle; iki bölümden oluşan bildirinin bu ilk bölümünde; gerek yaygın bir kullanım alanı olan ve gerekse kullanımı sonrasındaki çevresel etkileriyle sorunlar yaratan ve genel adı ile "Plastik" olarak adlandırılan malzemelere ait genel özellikleri, kullanım alanlarını, Dünya'da ve Türkiye'deki sektörel durum, plastiklerin geri kazanım yöntemleri ve ekonomisi irdelenmiştir. Ayrıca plastiklerin geri kazanımında en uygun yöntemlerden birisi olarak değerlendirilen flotasyon yöntemi, özellikle de kolon flotasyonu yöntemine ait temel özellikler verilmiştir.

Birinci bölümünde; genel bilgiler ve verilerin değerlendirildiği, bildirinin ikinci bölümünde ise; PVC ve PET ayırımında kolon flotasyonu uygulamasına ilişkin deneysel veriler ve sonuçları tartışlacaktır.

\section{KAYNAKLAR}

1. Alp, S., 2003. İstanbul Ticaret Odası Plastik Sektör Raporu.

2. Savaş̧ı, Ö. T., Uyanık, N., Akovalı, G., 2002. Ana Hatları ile Plastikler ve Plastik Teknolojisi, PAGEV Yayınları. 
3. Paci, M., La Mantia, F. P., 1999. Influence of Small Amounts of Polyvinylchloride on the Recycling of Polyethyleneterephthalate, Polymer Degradation and Stability, Cilt.63, S.11-14.

4. Singh, B. P., 1998. Wetting Mechanism in the Flotation Separation of Plastics, Filtration \& Separation, s.525 527.

5. Sevencan, F., Vaizoğlu, S. A., 2007. Pet ve Geri Dönüşümü, TSK Koruyucu Hekimlik Bülteni, Cilt.6 (4), s.307-312.

6. Kıralp, S., Özkoç G., Erdoğan, S., Çamurlu, P., Doğan, M., Baydemir, T., 2007. Modern Çağın Malzemesi Plastikler, ODTÜ Bilim ve Toplum Kitapları Dizisi ODTÜ Yayıncılık.

7. Güler, Ç., Çobanoğlu, Z., 1997. Plastikler, Sağlık Projesi Genel Koordinatörlügü.

8. Shen, H., Pugh, R. J., 2002. Forssberg, E., Floatability, Selectivity and Flotation Separation of Plastics by Using a Surfactant, Colloids and Surfaces A: Physicochemical and Engineering Aspects, Cilt.196, s.63-70.

9. Devlet Planlama Teşkilatı, 2001. Sekizinci Beş Yıllık Kalkınma Planı, Plastik Ürünleri Sanayi Özel İhtisas Komisyonu Raporu, DPT: 2547 ÖİK:563.

10. Url <http://www.plasticeurope.org>, alındı $\breve{g} 1$ tarih 08.11.2009.

11. Eraslan, İ. H., Karataş, A., Kaya, H., 2007. Türk Plastik Sektörünün Rekabetçilik Analizi, İstanbul Ticaret Üniversitesi Sosyal Bilimler Dergisi, Cilt.11, s.203-219.

12. Url <http://www.pagev.org.tr>, alındığ 27.10.2009.

13. Devlet Planlama Teşkilatı, Türkiye Plastik Sektörü Raporu, 2004.

14. Url <http://www.kimyamuhendisi.com>, alındı $\breve{g}_{1}$ tarih 09.01.2010.

15. Dinger, P., 1992. Automatic Microsorting for Mixed Plastics, BioCycle, Cilt.33(4), s.79-80.

16. Drelich, J., Payne, T., Kim, J. H., Miller, J. D., 1998. Selective Froth Flotation of PVC From PVC/PET Mixtures for the Plastics Recycling Industry, Polymer Engineering and Science, Cilt. 38(9) s.1378-1386.

17. Marques, G. A., Tenório, J. A. S., 2000. Use of Froth Flotation to Separate PVC/PET Mixtures, Waste Management, Cilt.20, s.265269.
18. Shen, H., Forssberg, E., Pugh, R. J., 1998. A Review of Plastics Waste Recycling and the Flotation of Plastics, Resources, Conservation and Recycling, Cilt.25, s.85-109.

19. Yarman, Ş., M., 2007. PETKİM Petrokimya Holding A.Ş., International POPs Elimination Project IPEP.

20. Url <http://www.wikipedia.org >, alındığ 27.10.2009.

21. Url <http://www.icis.com>, alındığı tarih 07.01.2010.

22. Url <http://www.lme.com>, alındığ1 tarih 09.01.2010.

23. Url <http://www.biastra.com>, alındığ tarih 5.10.2009.

24. Drelich, J., Kim, J. H., Payne, T., Miller, J. D., Kobler, R. W., 1999. Purification of Polyethylene Terephthalate from Polyvinyl Chloride by Froth Flotation for the Plastics (Soft-Drink Bottle) Recycling Industry, Separation and Purification Technology, Cilt.15, s.9-17.,

25. Le Guern, C., Conil, P., Houot, R., 2000. Role of Calcium Ions in the Mechanism of Action of a Lignosulphonate Used to Modify the Wettability of Plastics for their Separation by Flotation, Minerals Engineering, Cilt.13 (1) s.53-63.

26. Shen, H., Forssberg E., Pugh R. J., 2001. Selective Flotation Separation of Plastics by Particle Control, Resources, Conservation and Recycling Cilt.33, s.37-50.

27. Pascoe, R. D., O'Connell, B., 2003. Flame Treatment for the Selective Wetting and Separation of PVC and PET, Waste Management, Cilt.23, s.845-850.

28. Takoungsakdakun, T., Pongstabodee, S., 2006. Separation of Mixed Post Consumer PET-POM-PVC Plastic Waste Using Selective Flotation, Separation and Purification Technology, Cilt.54, s.248-252.

29. Yenial, Ü. 2007. PET ve PVC Artıklarının Kolon Flotasyonu ile Ayrılmasında Değişik Plastikleştirici Reaktiflerin Etkisinin İncelenmesi, Lisans Tezi, İTÜ Maden Fakültesi Maden Mühendisliği Bölümü.

30. Özdilek, C., 2009. PET ve PVC Artıklarının Kalsiyum Lignosülfonat ve Lignin Alkali Tipi Plastikleştirici Reaktifler Kullanılarak Seçimli 
Olarak Ayrılmasının Araştırılması, Lisans Tezi, İTÜ Maden Fakültesi Maden Mühendisliği Bölümü.

31. Kılıç, M., 2010. Katkılı PVC ve PET Atıklarının Seçimli Olarak Ayrılmasına Yönelik Kolon Flotasyonu Parametrelerinin Belirlenmesi, Yüksek Lisans Tezi, İTÜ Maden Fakültesi Maden Mühendisliği Bölümü.

32. Çilek, E., C., 1993. Düşük Tenörlü Kükürt Cevherlerinin Kolon Flotasyonu ile Kazanılmas1, Doktora Tezi, Osmangazi Üniversitesi, Fen Bilimleri Enstitüsü, Eskişehir.

33. Güney A., Atak S., 1993. Flotasyon ve Flokülasyon Cevher Hazırlama Teknolojisindeki Yeni Gelişmeler Konulu Meslek İçi Eğitim Semineri İTÜ Maden Fakültesi İstanbul, 6-10 Mayıs 1991, pp 1-30.

34. Öteyaka, B., and Soto, H., 1992. Modelling of Negative Bias Column for Coarse Particles Flotation, 4. Uluslararası Cevher Hazırlama Sempozyumu Bildirileri, Ekim, Antalya.

35. Jameson, G., J., A., 1998. New Concept in Flotation Column Design, Column Flotation 88, Sastry, K., V., S., (ed.), SME.

36. Finch, J.,A., Dobby, G.,S., 1991. Column Flotation: A Selected Review, Part II; Volume 4, Issue 7, Pages 911-923 Minerals Engineering, Elsevier Ltd.

37. Amelunxen R., L., 1985. The Mechanics of Operation of Column Flotation Machines, Proc. 17 th Meeting of the Canadian Mineral Processors,C.I.M., Ottawa, Jan. 1985, pp 13-31.

38. Plastik Atıkların Geri Kazanımına Yönelik Uygun Flotasyon Proseslerinin Geliştirilmesi, 2010. İTÜ Maden Fakültesi, Cevher Hazırlama Müh. Bölümü, TÜBİTAK MAG, 1001 Araştırma Projesi, Proje No:108M042, Aralık. 
